Provided for non-commercial research and education use. Not for reproduction, distribution or commercial use.

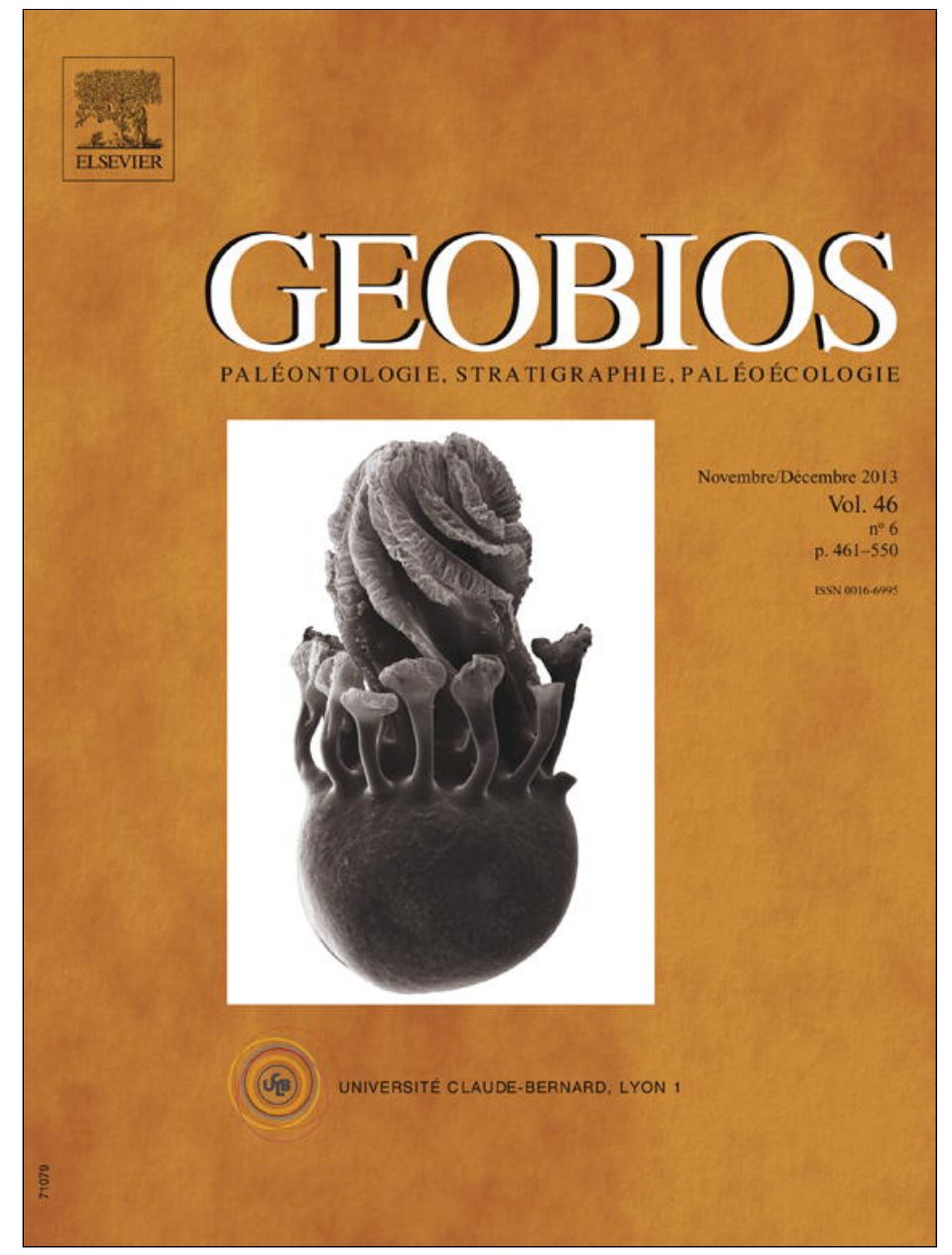

This article appeared in a journal published by Elsevier. The attached copy is furnished to the author for internal non-commercial research and education use, including for instruction at the authors institution and sharing with colleagues.

Other uses, including reproduction and distribution, or selling or licensing copies, or posting to personal, institutional or third party websites are prohibited.

In most cases authors are permitted to post their version of the article (e.g. in Word or Tex form) to their personal website or institutional repository. Authors requiring further information regarding Elsevier's archiving and manuscript policies are encouraged to visit:

http://www.elsevier.com/authorsrights 
Original article

\title{
Fish otoliths from the Pliocene Heraklion Basin (Crete Island, Eastern Mediterranean) ${ }^{\text {ir }}$
}

\author{
Konstantina Agiadi a,*, Efterpi Koskeridou ${ }^{a}$, Maria Triantaphyllou ${ }^{a}$, \\ Angela Girone ${ }^{\mathrm{b}}$, Vasileios Karakitsios ${ }^{\mathrm{a}}$ \\ ${ }^{a}$ Department of Historical Geology and Palaeontology, Faculty of Geology and Geoenvironment, National and Kapodistrian University of Athens, \\ Panepistimioupolis 15784, Athens, Greece \\ ${ }^{\mathrm{b}}$ Facoltà di Scienze, Dipartimento di Geologia e Geofisica, Campus Universitario, Via E. Orabona 4, 70125 Bari, Italy
}

\section{A R T I C L E I N F O}

\section{Article history:}

Received 24 February 2013

Accepted 31 July 2013

Available online 22 October 2013

\section{Keywords:}

Teleostei

Systematics

Palaeobiogeography

Zanclean

Pliocene

Eastern Mediterranean

\begin{abstract}
A B S T R A C T
The Pliocene Eastern Mediterranean fish record is revealed through the study of a 60-m thick stratigraphic sequence near the village Voutes (Heraklion, Crete). Forty-two species belonging to twenty families are identified. Calcareous nannoplankton biostratigraphy places the studied sequence within the biozone MNN16a (latest Zanclean). The stratigraphic distribution of 31 species is modified. Among these, 12 species are reported for the first time in the Eastern Mediterranean Zanclean, while 19 species are first reported outside the Ionian Sea. The Voutes fish fauna presents a diversified benthic and benthopelagic assemblage filling a significant gap in the fossil record.
\end{abstract}

(c) 2013 Elsevier Masson SAS. All rights reserved.

\section{Introduction}

Fish otoliths, the aragonitic incremental structures within the teleostean fish's inner ear, present taxon-specific morphology, which enables fossil fish assemblage reconstruction, since they are highly frequent in sediments of various environmental settings, ranging from lake to deep-sea deposits, and they are generally well preserved (Nolf, 1985). In addition, numerous studies have illustrated their value as palaeoecologic and palaeobathymetric indicators, providing very detailed and accurate palaeobiological and palaeoclimatic information.

The Pliocene Mediterranean fish fauna comprised typical tropical and subtropical taxa, which mostly inhabited the basin following its reconnection to the Atlantic Ocean, after the Messinian Salinity Crisis (Landini and Sorbini, 2005). Pliocene fish remains have been identified through several studies in the Western Mediterranean realm (Nolf and Martinell, 1980; Nolf and Girone, 2006; Girone, 2007). However few studies have been performed in the eastern subbasin, almost all currently available information coming from fish skeletal remains. New Zanclean otolith-based fish fossil data for the Eastern Mediterranean basin are presented here for the first time, through the systematic study and analysis of the Zanclean fish otolith assemblages of the Voutes section (Heraklion, central Crete).

\footnotetext{
Corresponding editor: Gilles Escarguel.

* Corresponding author.

E-mail address: kagiadi@geol.uoa.gr (K. Agiadi).
}

\section{Geological setting}

The Crete Island originated during the late Miocene through the $\mathrm{N}-\mathrm{S}$ and E-W extensional deformation of the south Aegean, resulting in the formation of multiple tectonic blocks and late Miocene to Pleistocene sedimentary basins (Meulenkamp et al., 1988; Van Hinsbergen and Meulenkamp, 2006). The Neogene sediments overlie a pile of alpine nappe substratum, which includes the metamorphic Plattenkalk and Phyllites-Quarzites Units followed by the Tripolis and Pindos-Ethia, as well as other minor units (Zachariasse et al., 2011).

The presently emerged area of the Heraklion Basin is a Pliocene graben structure located at the northern part of the central Crete Island, in the southern segment of the Hellenic Arc, between the mountains Psiloritis and Dicti. The alpine basement formations contain a rich mélange of Triassic to Eocene sedimentary and metamorphic rocks, overlain by Neogene and Quaternary sedimentary deposits, recording a great diversity of environments and ecosystems (Symeonidis and Konstadinidis, 1967). The Pliocene Heraklion Basin occurred in a region marked by a great number of successive paleogeographic Miocene frameworks, in the vicinity of the Messara basin. In the latest Tortonian the activation of the EW-oriented Agia Varvara fault differentiated the two realms, which evolved separately since that time (Delrieu et al., 1991). The Pliocene deposits of the Heraklion Basin are the most extensive ones in the Island. The marine sediments of the lowermost Pliocene generally overlie the late Messinian deposits (Delrieu et al., 1991; 
Meulenkamp et al., 1979, 1994), and consist of whitish marls and marly limestones of deep-water origin, reflecting the Pliocene flooding which followed the lago-mare episode immediately after the Mediterranean Salinity Crisis.

The studied Voutes section is located southwest of the village Voutes in central Crete, south of Heraklion city. Geologically it is situated in the western section of the Heraklion Basin (Fig. 1). The section sediments may be placed within the Finikia lithostratigraphic group of Benda et al. (1974) and Meulenkamp et al. (1979); they include more than $60 \mathrm{~m}$ of marls and sandy marls (Figs. 2-4). On the lower part of the section, strong gravity flows have formed a series of sand lenses with distinctive sedimentological attributes and characteristic fauna (Fig. 5). The upper part of the section presents three diatomite horizons.

\section{Material and methods}

Overall, nine sediment samples were taken; $25 \mathrm{~kg}$ each, along the Voutes section (Figs. 2 and 3). Sample 1 was taken from the uppermost diatomite horizon, which is bare of other faunal remains. Sample 2 was collected from the uppermost marls, which present a rather rich macro-invertebrate fauna, including
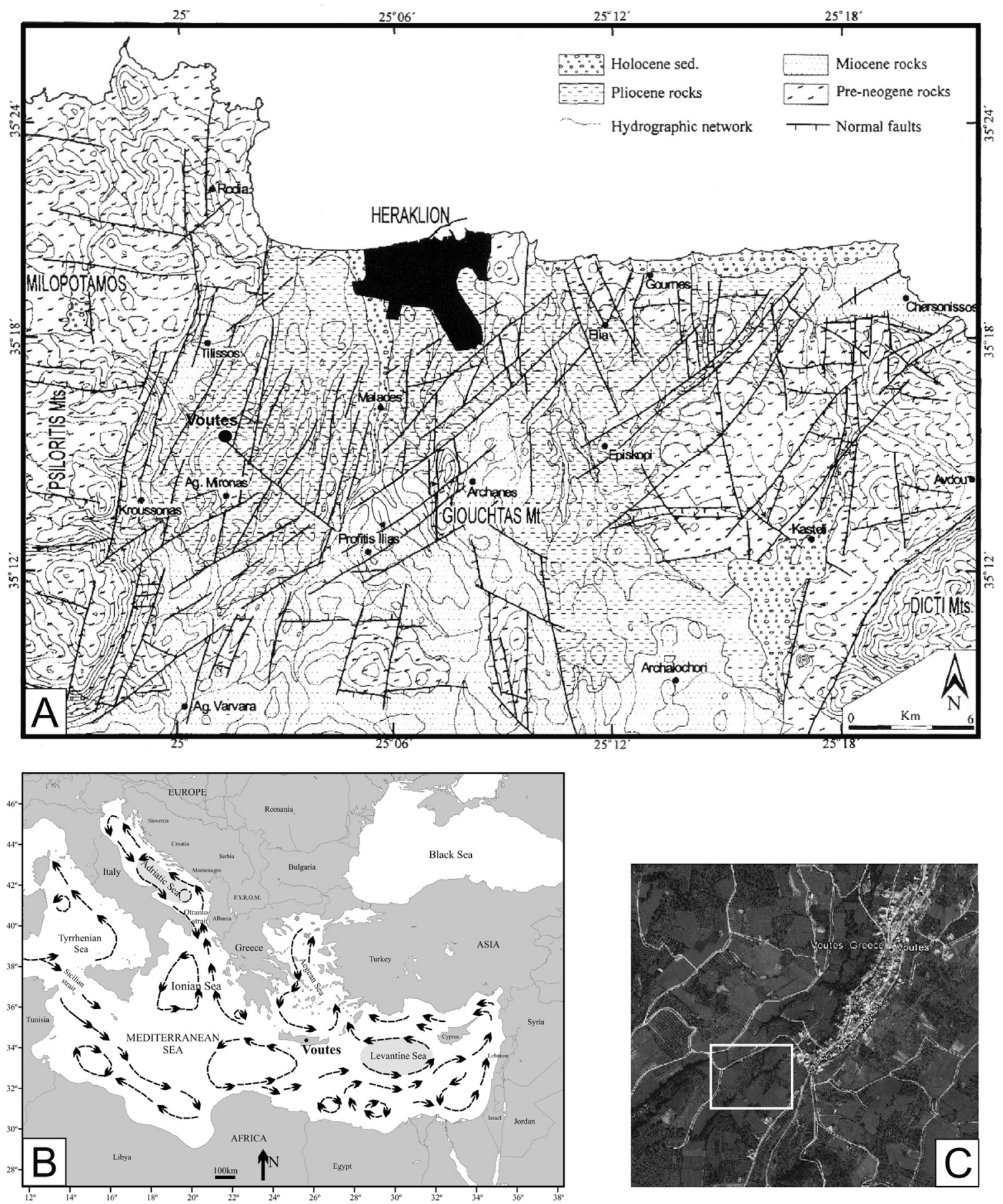

Fig. 1. Location of the study area. A. Geological map of the Heraklion area (simplified after Fassoulas, 2001), indicating the Voutes village. B. Map of the Eastern Mediterranean including the major circulation patterns. Grey sea areas denote deep-water formation regions. C. Photograph of the study area (obtained from Google Earth). The square marks the extent of the Voutes outcrop. 


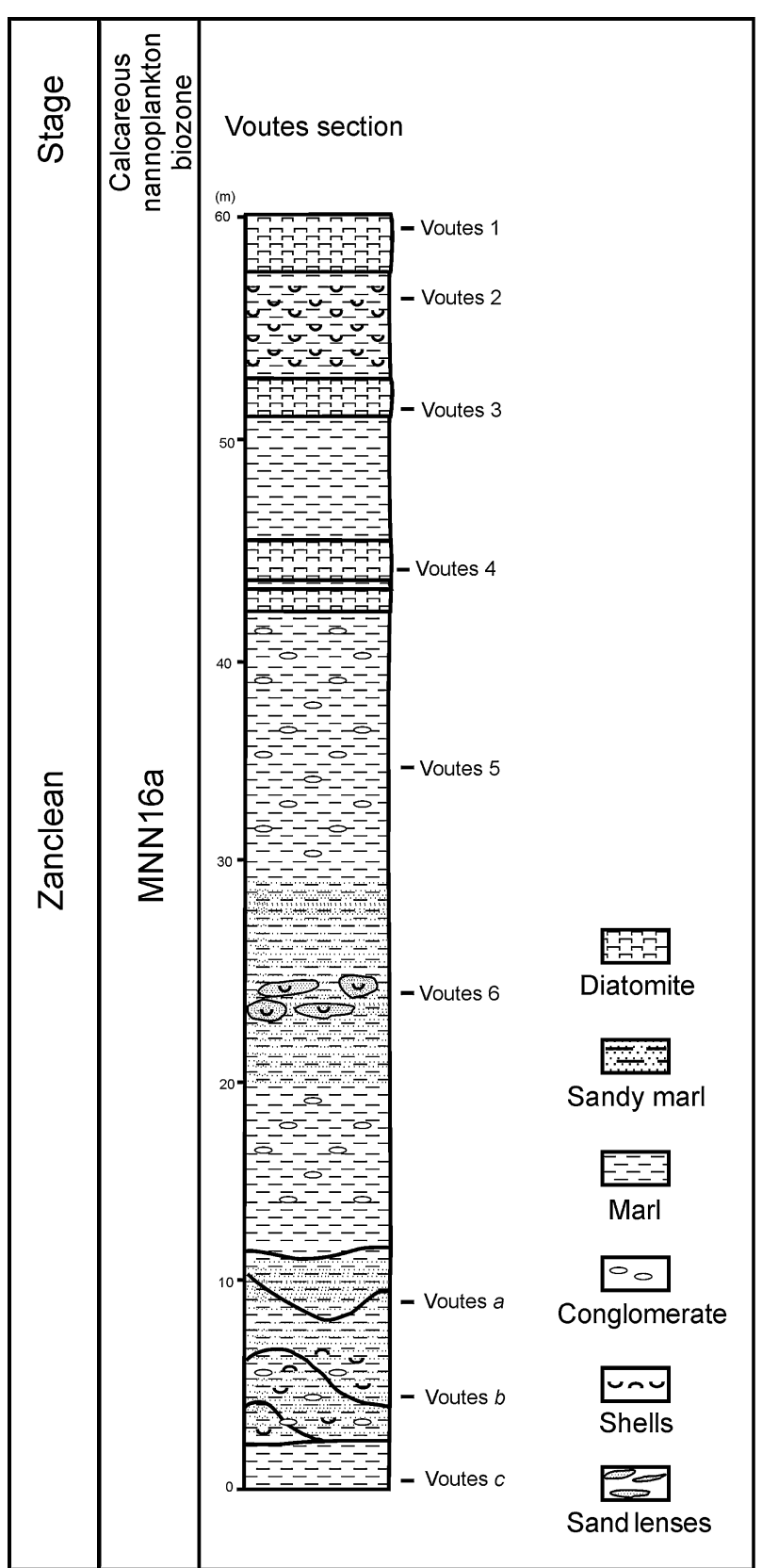

Fig. 2. Stratigraphic column of the Voutes section, indicating sample location. Calcareous nannofossil biozonation following Rio et al. (1990).

nuculoids, pectinids and limids. Samples 3 and $\mathbf{4}$ were taken from the second and third diatomite horizons, respectively, which present a poor macro-invertebrate fauna of deep-water bivalves. Sample 5 was taken from the blue marls, at the middle part of the section, where pteropods, nuculoids, thin pectinids and Cadulus were also identified. Sample 6 comes from marly sands, mostly gravity flows, with pectinids and gastropods. Sample $\boldsymbol{a}$ was collected from sandy marls with Neopycnodonta navicularis, pectinids and gastropods. Sample $\boldsymbol{b}$ was taken from one of the sand gravity lenses observed at the lower part of the outcrop (Fig. 5), which also include macrofossils such as naticids, pectinids, venerids, cardiids, turritellids and cerithiids. At the lowermost part of the section, sample $c$ was collected from the marls underneath and around the sand lenses, in which the macroscopic examination showed no evidence of other faunal remains. The microscopic examination of this lowermost bed
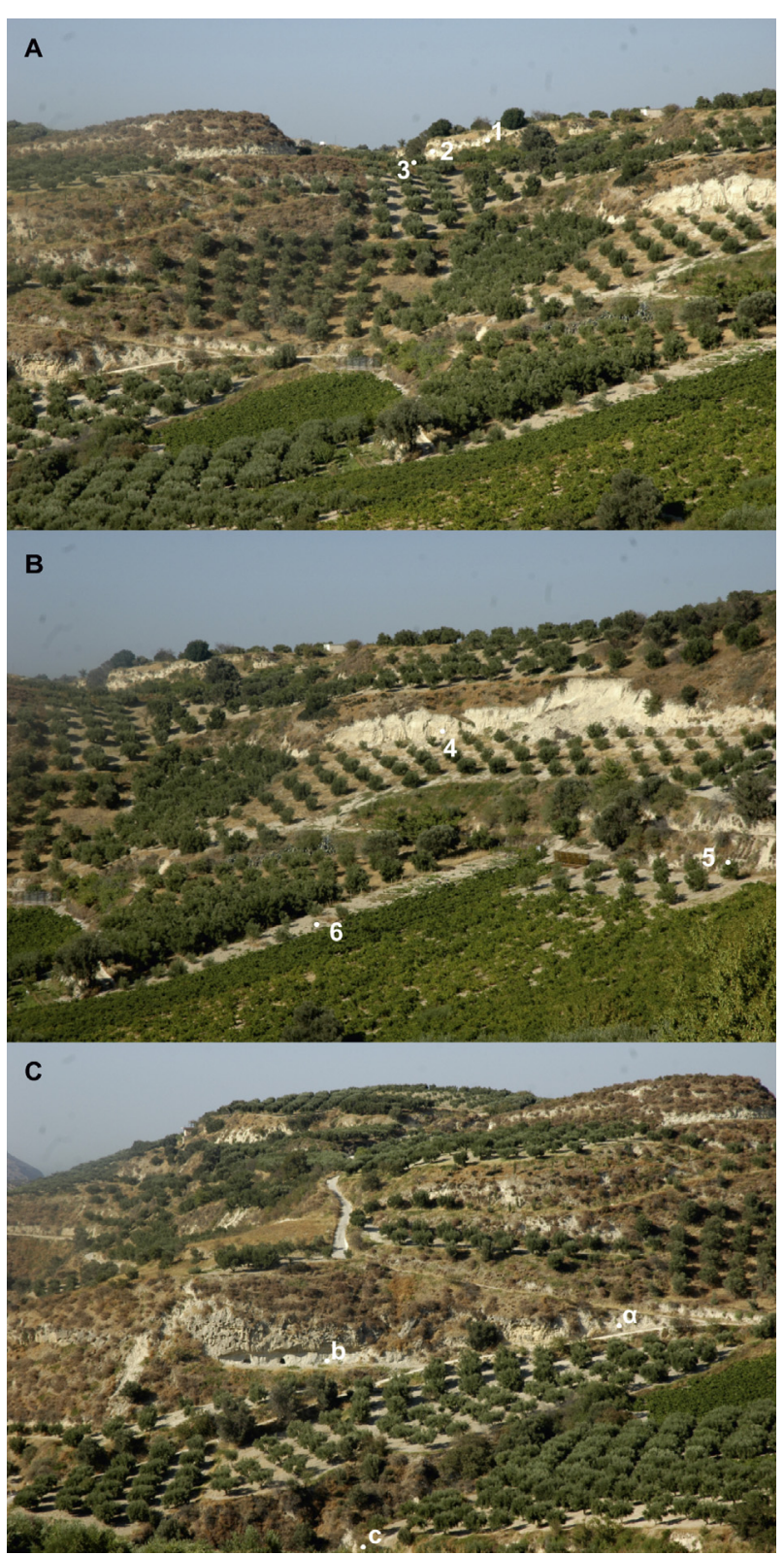

Fig. 3. Photographs of the Voutes section, with sample location. A. Upper part of the section (samples 1-3). B. Intermediate part (samples 4-6). C. Lower part (samples $a-c)$.

revealed the presence of bathyal mollusc elements such as Kelliella milliaris, Limopsis spp., and Ledella sp. The samples were washed and sieved in plain water, using a $250 \mu \mathrm{m}$-diameter sieve. The otoliths were then handpicked from the sediment under a stereoscope.

The fish otoliths were identified based on the morphological characteristics described by Nolf (1985); lapilli were described and identified based on Assis (2005). The species' taxonomic position follows Nelson's (2006) scheme. Many recent fish species were already identified in the Mediterranean Pliocene, but in several cases, specific assignment could not be unequivocally decided, as indicated by the abbreviation "aff." inserted between the name of the genus and the name of the group species. The abbreviation "cf." was used whenever the condition of preservation of the otolith did not allow conclusive specific identification. Moreover, several taxa appear in open nomenclature at the species level due to 


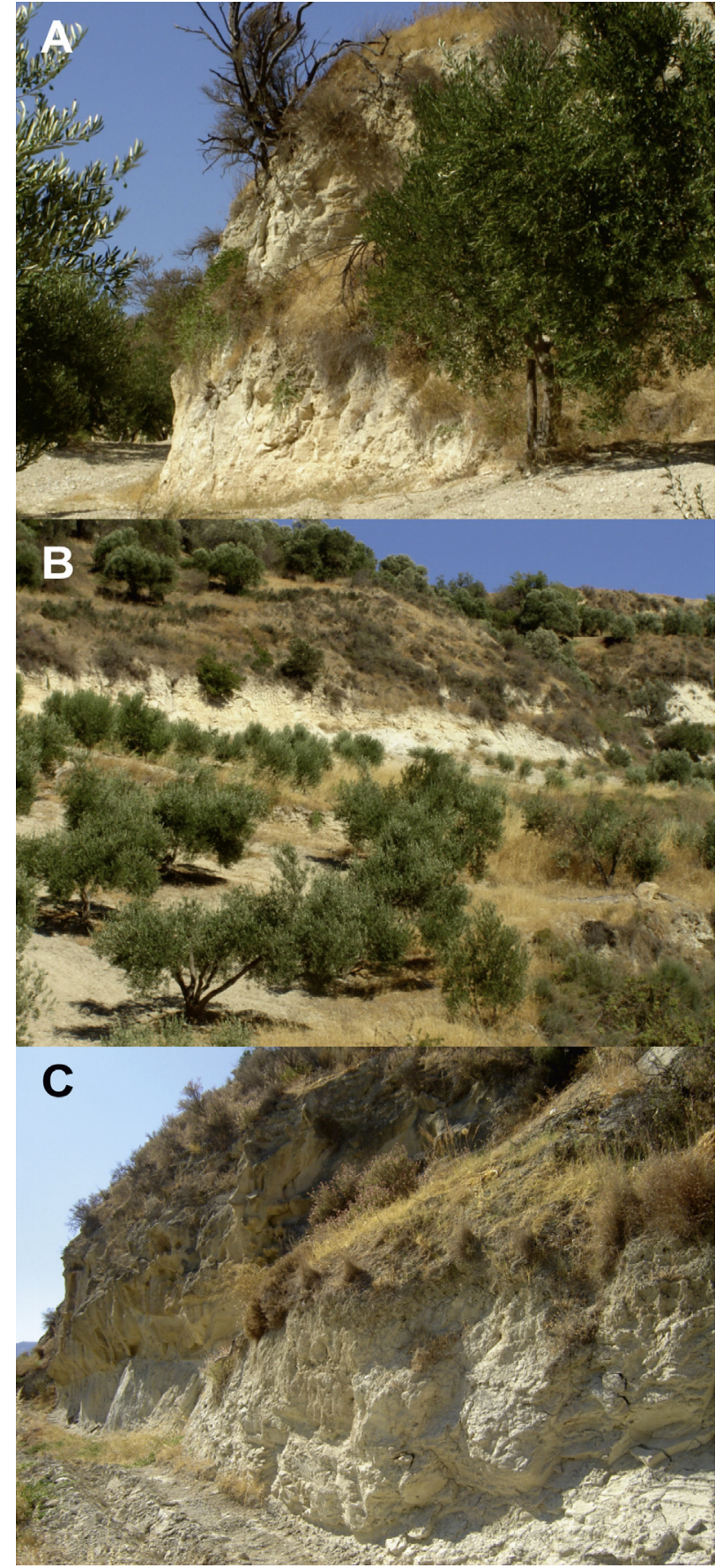

Fig. 4. Photographs of the sampled outcrops, showing different studied intervals A. Upper diatomite horizon. B. Middle part of the section. C. Lower part of the section, incorporating the sand lenses.

insufficient knowledge of related recent species or because the fossil material is too limited or too poorly preserved to decide.

Selected otoliths from each taxon were photographed using the scanning electron microscope JEOL JSM-6360 of the Department of Historical Geology and Paleontology of the University of Athens. The identified material is stored at the Athens Museum of Paleontology and Geology.

The relevant chronostratigraphic framework (Fig. 2) for the evaluation of the results was provided through calcareous nannoplankton biostratigraphy, based on Rio et al.'s (1990) biozonation scheme as incorporated in the magnetobiochronologic framework of Lourens et al. (2004) in Gradstein et al. (2004). Numerical ages of biozone boundaries follow Lourens et al. (2004) and Raffi et al. (2006). In addition, the relative abundance of Discoaster spp. was measured in order to further specify the stratigraphic interval under study.

The palaeobiogeographic distributions of the identified Teleostei were compared to equivalent assemblages across the Mediterranean realm in order to fill gaps in the fossil record as well as to identify ichthyofauna differences and similarities.

\section{Systematic palaeontology}

Altogether, 42 taxa from 20 families were identified in the Voutes section sediments (Fig. 6). Specific notes on their identifications and systematic placement are made below wherever necessary.

Class ACTINOPTERYGII Klein, 1885

Order ANGUILLIFORMES Berg, 1940

Family CONGRIDAE Kaup, 1856

Genus Pseudophichthys Roule, 1915

Pseudophichthys spp.

Fig. 7(3)

Remarks: Two specimens are placed within this genus, based on the ostium portion of the sulcus, which is only very shallow and consequently poorly definable, in contrast to other congrids. One specimen is unequivocally comparable to the extant Atlantic Pseudophichthys splendens, also already reported from the Western Mediterranean Pliocene (Nolf and Girone, 2006; Girone, 2007), while the other (Fig. 7(3)) is better placed under the fossil species Pseudophichthys escavaratierensis, also known from the Pliocene of Southern France (Schwarzhans, 1986; Nolf and Cappetta, 1988). These two Pseudophichthys specimens noticeably differ in the placement of the postero-dorsal angle. Moreover, P. escavaratierensis has a more rounded posterior margin and a more regularly-curved dorsal margin than $P$. splendens.

Genus Rhynchoconger Jordan and Hubbs, 1925

Rhynchoconger pantanellii (Bassoli and Schubert, 1906)

Fig. 7(4)

Remarks: The otoliths placed under this fossil Mediterranean species are well distinguished from Conger conger and Pseudophichthys spp. by the closed sulcus, connected to the periphery only through a well-marked and rimed ostial channel almost vertical to the sulcus and the dorsal margin. The Voutes specimens are very similar to the otoliths of the fossil species Rhynchoconger (Hildebrandia) pantanellii, also known from the Pliocene sediments of Northern Italy and Southern France (Nolf and Cappetta, 1988; Girone, 2007).

Order AULOPIFORMES Rosen, 1973

Family CHLOROPHTHALMIDAE Jordan, 1923

Genus Chlorophthalmus Bonaparte, 1840

Chlorophthalmus agassizi Bonaparte, 1840

Fig. 7(2)

Remarks: The unique specimen found in Voutes sediments is the only known Pliocene record of this species. Previously this genus has been referred with the species Chlorophthalmus costamagnai Schwarzhans, 1986 from the early Pliocene of Le Puget (Southern France; Nolf and Cappetta, 1988) and Papiol (Spain; Nolf et al., 1998), and with Chlorophthalmus cf. agassizi from the Middle Pleistocene of Kephallonia (Eastern Ionian Sea; Agiadi et al., 2010). The Voutes specimen exhibits all the morphological characteristics of the modern Mediterranean species C. agassizi much better than the Kephallonia specimen. Namely, the Voutes specimen has an elongated shape with almost parallel dorsal and ventral margins, a long linear cauda and a much smaller ostium, which open antero-dorsally. The anterior and posterior dorsoventral areas are almost equal, in contrast to both $C$. costamagnai and $C$. cf. agassizi. 


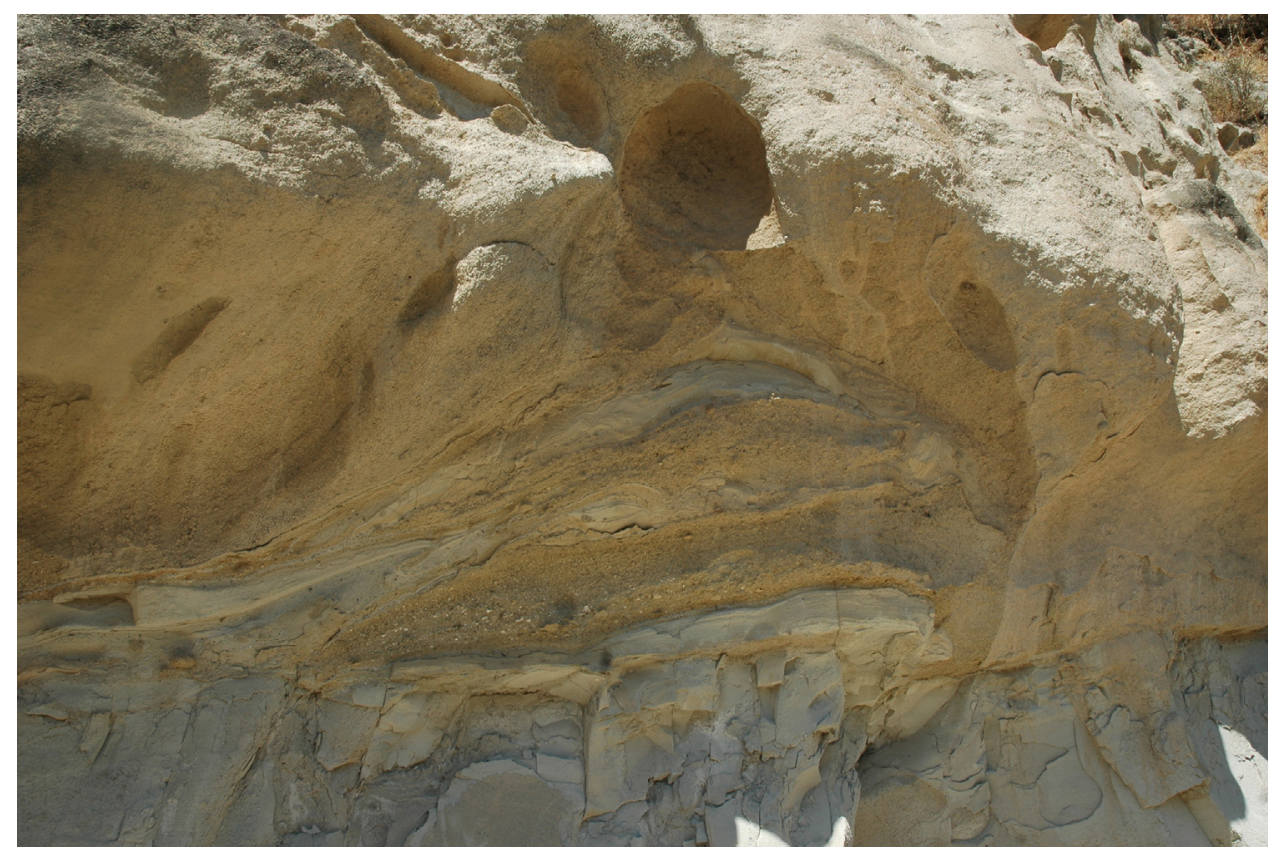

Fig. 5. Gravity flows at the lower part of the Voutes section.

Order MYCTOPHIFORMES Regan, 1911

Family MYCTOPHIDAE Gill, 1893

Genus Diaphus Eigenmann and Eigenmann, 1890

Diaphus spp.

Fig. $7(5-7,11,12,14)$

Remarks: Overall, six Diaphus species are recognized in the Voutes material. Diaphus otolith morphology is known to vary greatly with fish age and as such, specific identification can be unequivocally made only with adult specimens of good preservation (Brzobohaty and Nolf, 2000). The otoliths of Diaphus holti (Fig. 7(7)) and $D$. rafinesquii (Fig. 7(14)) are both characterized by a strongly denticulate ventral margin, well-developed rostrum and a salient postero-dorsal angle. However $D$. rafinesquii is notably lengthier than $D$. holti; the latter has a greater height/length ratio. In addition, the sulcus of $D$. holti has a nearly rounded caudal colliculum, while it is elongate in $D$. rafinesquii. Six otoliths can be compared with those of the recent Atlantic Diaphus taaningi (Fig. 7(11)), characterized by a subquadrangular shape and a wide predorsal angle. This species is represented here only by juvenile and young adult specimens, slightly more elongate than recent material. A similar observation is made in the adult and juvenile specimens of $D$. taaningi from the Early Pleistocene of Montalbano (Western Ionian) and the EarlyMiddle Pleistocene of Archi (Western Mediterranean; Girone et al., 2006). However, the revision of this taxon proposed by Brzobohaty and Nolf (2000) pointed out that the Pliocene specimens tend to be slightly more elongate than the studied recent material. The same authors also observed such an elongate morphology in specimens from the Early Pliocene of Dar Bel Hamri, Atlantic Morocco. Several specimens present great similarity with the small and mediumsized specimens from Northern Italy (Nolf and Girone, 2006), which were identified as Diaphus aff. adenomus (Fig. 7(6)).

Order PERCIFORMES Bleeker, 1859

Family ACROPOMATIDAE Gill, 1893

Genus Parascombrops Alcock, 1889

Parascombrops mutinensis Bassoli, 1906

Fig. 7(18-21)

Remarks: The three otoliths of this species described here share the same morphological characteristics with all the Pliocene and Pleistocene material described from Western Mediterranean (Nolf and Martinell, 1980; Nolf and Girone, 2006). P. mutinensis specimens from the Early Pleistocene Eastern Ionian basin (Agiadi et al., 2010) had a considerably underdeveloped antero-ventral area. Two specimens in the Voutes material are from adult individuals, and both exhibit a well-developed antero-ventral area. However, the third specimen, belonging to a smaller individual, is undoubtedly smaller in this part, being similar to the Akrotiri specimens (Eastern Ionian). Through direct comparison with the Akrotiri specimen and small and large specimens from Palione river (Di Geronimo et al., 2003), it becomes evident that this difference is within the ontogenetic variability of the species; the antero-dorsal area seems to develop in later stages.

Family GOBIIDAE Cuvier, 1816

Fig. 8(13-20, 24)

Remarks: The members of this family have otoliths with very similar morphological characteristics. The most significant diagnostic characters are the size, shape and placement of the central or off-central sulcus and the overall shape of the otolith. The otoliths of Aphia minuta (Fig. 8(19)) are very small, oval-shaped, with a concave inner surface. The sulcus is also small and undivided, while the dorsal margin is irregularly curved. Twelve specimens, even if partially eroded, may be safely identified as Deltentosteus quadrimaculatus otoliths. However the Voutes specimens show greater similarity with the otoliths of $D$. aff. quadrimaculatus described from the Early Pleistocene of Northern Italy (Nolf and Girone, 2000, 2006; Girone, 2007), which has a more blunt antero-ventral angle than D. quadrimaculatus. The specimen identified here as Gobius sp.1 (Fig. 8(13)) strongly resembles Gobius sp. from the Pliocene and Pleistocene sediments of Northern Italy (Nolf and Girone, 2000, 2006). In addition, one gobiid specimen exhibits a very characteristic morphology, but cannot be specifically identified, and is referred here to genus "Gobidarum" sp.1 (Fig. 8(20)). This is a small square otolith; the posterior and anterior rims are angled outwards. The sulcus is also small and resembles that of Aphia minuta, exhibiting a concave inner face.

Order GADIFORMES Goodrich, 1909

Family GADIDAE Rafinesque, 1810

Fig. 8(4) 


\begin{tabular}{|c|c|c|c|c|c|c|c|c|c|c|}
\hline \multirow[b]{2}{*}{ Family } & \multirow[b]{2}{*}{ Genus and Species } & \multicolumn{2}{|c|}{ Samples } & \multirow[b]{2}{*}{$\mathbf{a}$} & \multirow[b]{2}{*}{6} & \multirow[b]{2}{*}{5} & \multirow[b]{2}{*}{4} & \multirow[b]{2}{*}{3} & \multirow[b]{2}{*}{2} & \multirow[b]{2}{*}{1} \\
\hline & & c & b & & & & & & & \\
\hline \multicolumn{11}{|c|}{ PELAGIC TAXA } \\
\hline Sternoptychidae & Maurolicus muelleri (Gmelin, 1789) & - & - & 1 & - & - & - & 1 & - & - \\
\hline Phosichthyidae & Vinciguerria poweriae (Cocco, 1838) & 4 & - & 2 & 3 & 2 & - & - & - & - \\
\hline \multirow[t]{16}{*}{ Myctophidae } & Ceratoscopelus maderensis (Lowe, 1839) & 9 & - & 5 & 18 & 12 & 1 & 5 & 14 & - \\
\hline & Diaphus aff. adenomus Gilbert, 1905 & 2 & - & - & 2 & 5 & - & 4 & 1 & - \\
\hline & Diaphus cavallonis (Brzobohaty and Nolf, 2000) & 7 & - & 15 & 6 & 3 & 1 & 6 & 13 & - \\
\hline & Diaphus holti Taaning, 1918 & - & - & 7 & 4 & 13 & 1 & - & 1 & - \\
\hline & Diaphus rafinesquii $($ Cocco, 1838) & 2 & - & - & - & - & - & - & - & - \\
\hline & Diaphus aff. splendidus (Brauer, 1904) & - & - & 3 & 7 & 7 & - & 1 & 4 & - \\
\hline & Diaphus taaningi Norman, 1930 & - & - & 6 & - & - & - & - & - & - \\
\hline & Diaphus sp. & 50 & 8 & 65 & 11 & 8 & - & 5 & 42 & - \\
\hline & Hygophum benoiti (Cocco, 1838$)$ & - & - & - & - & - & - & - & 1 & - \\
\hline & Hygophum hygomii (Lütken, 1892) & 6 & - & - & 1 & 3 & 2 & 3 & 3 & - \\
\hline & Lobianchia dofleini (Zugmayer, 1911) & - & - & 5 & - & - & - & - & - & - \\
\hline & Myctophum fitchi (Schwarzhans, 1979) & 1 & - & 11 & 2 & - & 1 & - & 4 & - \\
\hline & Notoscopelus resplendens (Richardson, 1845) & 2 & - & - & 5 & 4 & - & - & - & - \\
\hline & Notoscopelus sp. & - & - & - & - & - & - & 2 & - & - \\
\hline & Scopelopsis pliocenicus (Anfossi \& Mosna, 1976) & - & - & - & - & 2 & 1 & - & - & - \\
\hline & indet. & 6 & 2 & 12 & 5 & - & - & 1 & 5 & 5 \\
\hline \multirow[t]{2}{*}{ Bregmacerotidae } & Bregmaceros sp. & 2 & 19 & - & 11 & 23 & 47 & 42 & 7 & 24 \\
\hline & & - & - & - & - & - & - & - & - & - \\
\hline BENTHIC AN & BENTHOPELAGIC TAXA & & & & & & & & & \\
\hline Congridae & Pseudophichthys splendens (Lea, 1913) & - & - & - & 1 & - & - & - & - & - \\
\hline & Pseudophtichthys escavaratierensis (Nolf and Cappetta, 1988) & - & - & - & - & - & - & 1 & - & - \\
\hline & Rhynchoconger pantanellii (Bassoli, 1906) & - & - & 1 & 3 & - & - & - & - & - \\
\hline Chlorophthalmidae & Chlorophthalmus agassizi Bonaparte, 1840 & - & - & - & - & 1 & - & - & - & - \\
\hline Moridae & Laemonema sp. & - & - & 1 & - & - & 2 & - & - & 1 \\
\hline Gadidae & Gadiculus labiatus (Schubert, 1905) & 2 & - & 3 & 6 & 4 & - & - & 9 & 1 \\
\hline & Indet. lapilli & 5 & - & - & - & 7 & - & - & 2 & 1 \\
\hline Bythitidae & Grammonus ater (Risso, 1810) & 2 & - & - & - & - & - & - & - & - \\
\hline Carapidae & Echiodon dentatus (Cuvier, 1829) & - & - & 1 & 1 & - & - & - & - & - \\
\hline Atherinidae & Atherina boyeri Risso, 1810 & - & - & - & 1 & - & - & - & - & - \\
\hline Apogonidae & Apogon sp. & 1 & - & - & 1 & - & - & - & - & - \\
\hline Epigonidae & Epigonus aff. denticulatus Dieuzeide, 1950 & 2 & - & - & - & - & - & - & - & - \\
\hline & Epigonus sp. & - & - & - & - & - & - & - & 1 & - \\
\hline Acropomatidae & Parascombrops mutinensis (Bassoli, 1906) & - & - & - & - & 2 & - & 2 & - & - \\
\hline Sparidae & Oblada melanura (Linnaeus, 1758 ) & 1 & - & - & - & - & - & 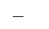 & - & - \\
\hline & Pagellus erythrinus (Linnaeus, 1758) & - & - & - & - & 1 & - & - & - & - \\
\hline & Pagellus sp. & - & - & - & 1 & - & - & - & - & - \\
\hline & Indet. & - & 1 & 8 & - & - & 1 & - & - & 1 \\
\hline Cepolidae & Cepola macrophthalma (Linnaeus, 1758) & - & 1 & - & 1 & - & - & - & - & - \\
\hline Perciformes & Indet. & - & - & 2 & 6 & - & - & 4 & 1 & 1 \\
\hline Gobiidae & Aphia minuta (Risso, 1810) & - & - & 2 & - & 2 & - & 1 & - & - \\
\hline & Deltentosteus aff. quadrimaculatus (Valenciennes, 1837) & - & 4 & 8 & - & - & - & - & - & - \\
\hline & Gobius niger Linnaeus, 1758 & - & - & 24 & - & - & - & - & - & - \\
\hline & Gobius cf. paganellus Linnaeus, 1758 & - & - & 1 & - & - & - & - & - & - \\
\hline & Gobius sp.1 & - & - & - & 1 & - & - & - & - & - \\
\hline & Gobius sp. & - & - & 3 & - & - & - & - & - & - \\
\hline & Lesueurigobius friesii (Malm, 1874) & - & 8 & 15 & 11 & 1 & - & - & - & - \\
\hline & Lesueurigobius sanzi (de Buen, 1918) & - & - & 4 & - & - & - & - & - & - \\
\hline & Lesueurigobius suerii (Risso, 1810) & 1 & - & 2 & 11 & - & - & - & - & - \\
\hline & Lesueurigobius $\mathrm{sp}$. & - & - & - & - & 1 & - & 1 & 4 & - \\
\hline & genus «Gobidarum» sp.1 & - & - & - & 1 & - & - & - & - & - \\
\hline & Indet. & - & 2 & 15 & 13 & 1 & - & - & - & - \\
\hline Trichiuridae & Indet. & - & - & - & - & - & - & - & 1 & - \\
\hline Citharidae & Citharus linguatula (Linnaeus, 1758) & - & - & - & 1 & - & - & - & - & - \\
\hline Bothidae & Arnoglossus kokeni (Bassoli, 1906) & - & - & 1 & - & - & - & - & - & - \\
\hline & Arnoglossus sp. & - & - & - & 1 & - & - & - & - & - \\
\hline & Indet. & - & - & 1 & - & - & - & - & - & - \\
\hline & Total number of otoliths & 105 & 45 & 224 & 135 & 102 & 57 & 79 & 113 & 34 \\
\hline
\end{tabular}

Fig. 6. List of the fish taxa identified in the Voutes section.

Remarks: All the Gadidae identified in the present material undoubtedly belong to the fossil Mediterranean species G. labiatus. In addition several lapilli are present in the samples (Fig. 8(4)). These exhibited similar morphological characteristics, so they were grouped together. Through comparison with the descriptions given by Assis (2005), these can safely be placed within Gadidae, with no further identification possible at this time. The specimens were thick, square-shaped with rounded margins. A strong, almost square voluminous protuberance is clearly contained within the otolith margin, when observed from the ventral view.

\section{Order PLEURONECTIFORMES}

Fig. 8(21-23)

Remarks: Pliocene and Pleistocene Arnoglossus otoliths from the Mediterranean realm have previously been placed under the fossil species $A$. kokeni, which has a linear or convex posterior margin. In extant Mediterranean species A. laterna the posterior margin is concave and irregular, occasionally even more slender. The Voutes specimen (Fig. 8(22)) exhibits greater similarity to A. kokeni in the sulcus, which is subparallel to the dorsal rim, in contrast to A. laterna where it is always parallel.

\section{Discussion}

\subsection{Biostratigraphy}

In the Voutes section, the nannoflora assemblage is dominated by discoasterids, which provide important biostratigraphic markers in the Pliocene. Discoasters are relatively well diversified and contain Discoaster adamanteus, D. assymetricus, $D$. tamalis, D. surculus, and very sporadic $D$. pentaradiatus and D. brouweri.

Placoliths are represented mainly by very abundant Pseudoemiliania lacunosa. Helicosphaera sellii is also significantly contributing to nannofossil assemblages. Reticulofenestra pseoudoumbilicus (> $7 \mu \mathrm{m})$ and sphenolithids are practically absent. The high abundance of both D. tamalis (15-35\%) and D. surculus (15-50\%) implies correlation with nannofossil zone MNN16 (Rio et al., 1990). Moreover, the nearly absence of $D$. pentaradiatus supports the recognition of the paracme interval of this species. Therefore the studied interval from the Voutes section is assigned to the biozone MNN16, above the highest occurrence of $R$. pseudoumbilicus and 


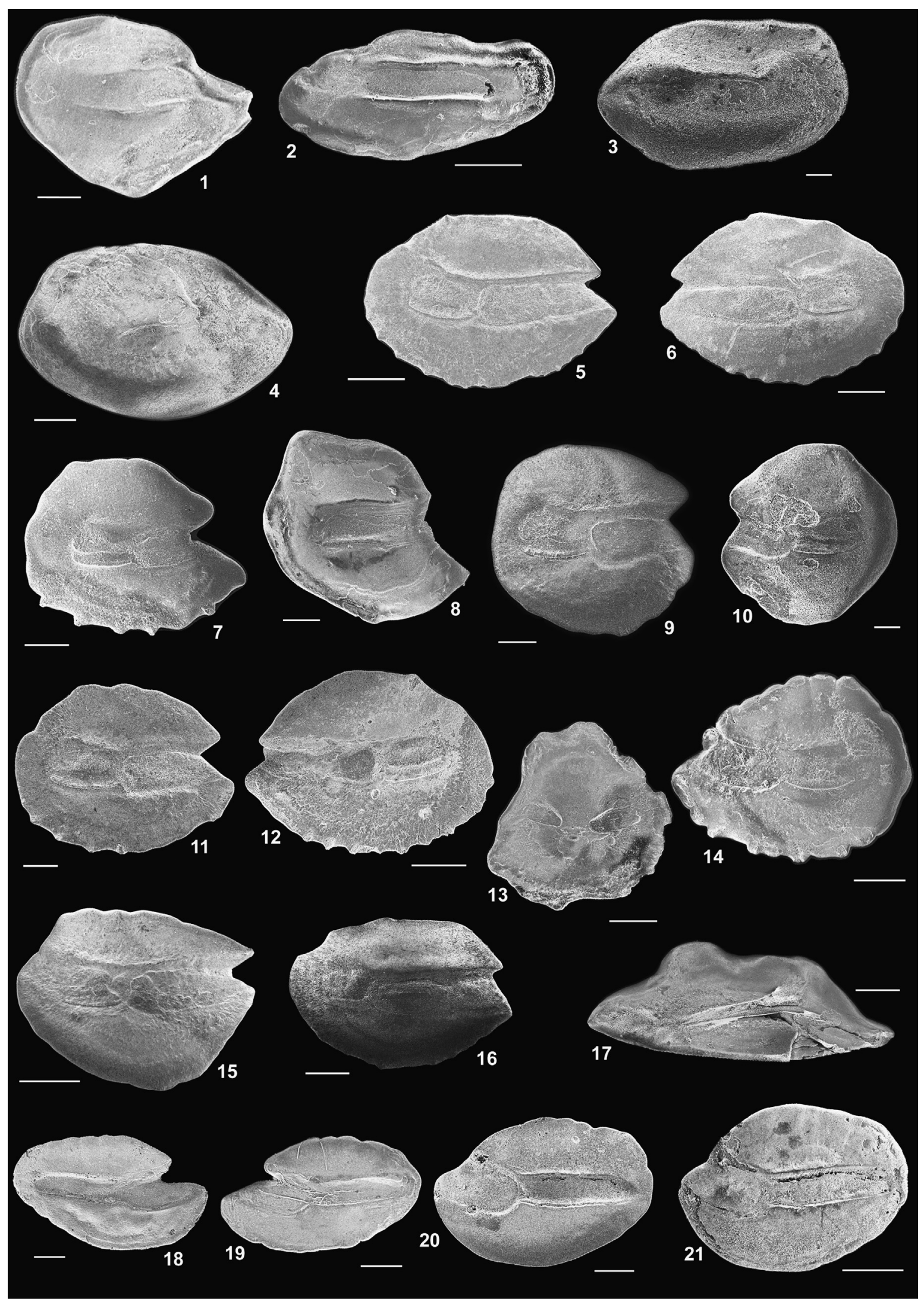

Fig. 7. SEM photographs of the studied otolith material. 1. Vinciguerria poweriae (Cocco, 1838), Voutes 5. 2. Chlorophthalmus agassizi Bonaparte, 1840, Voutes 5. 3. Pseudophichthys escavaratierensis (Nolf and Cappetta, 1988), Voutes 3. 4. Rhynchoconger pantanellii (Bassoli, 1906), Voutes a. 5. Diaphus aff. splendidus (Brauer, 1904), Voutes 5. 6. Diaphus aff. adenomus Gilbert, 1905, Voutes 2. 7. Diaphus holti Taaning, 1918, Voutes 2. 8. Maurolicus muelleri (Gmelin, 1789), Voutes 3. 9. Hygophum hygomii (Lutken, 1892), Voutes 3. 10. Hygophum benoiti (Cocco, 1838), Voutes 2. 11. Diaphus taaningi Norman, 1930, Voutes a. 12. Diaphus cavallonis (Brzobohaty and Nolf, 2000 ), Voutes 2. 13. Bregmaceros sp., Voutes 5. 14. Diaphus rafinesquii (Cocco, 1838), Voutes c. 15. Myctophum fitchi (Schwarzhans, 1979), Voutes c. 16. Notoscopelus resplendens (Richardson, 1845), Voutes c. 17. Laemonema sp., Voutes 4. 18-21. Parascombrops mutinensis (Bassoli, 1906); 18-20: eastern Ionian (Agiadi et al., 2010); 21 : Voutes 5. Scale bars: 200 $\mu$ m (1, 3, 8, 10); $500 \mu \mathrm{m}(2,4,7,9,11,13,14,17-19) ; 1 \mathrm{~mm}(5,6,12,15,16,20,21)$. 


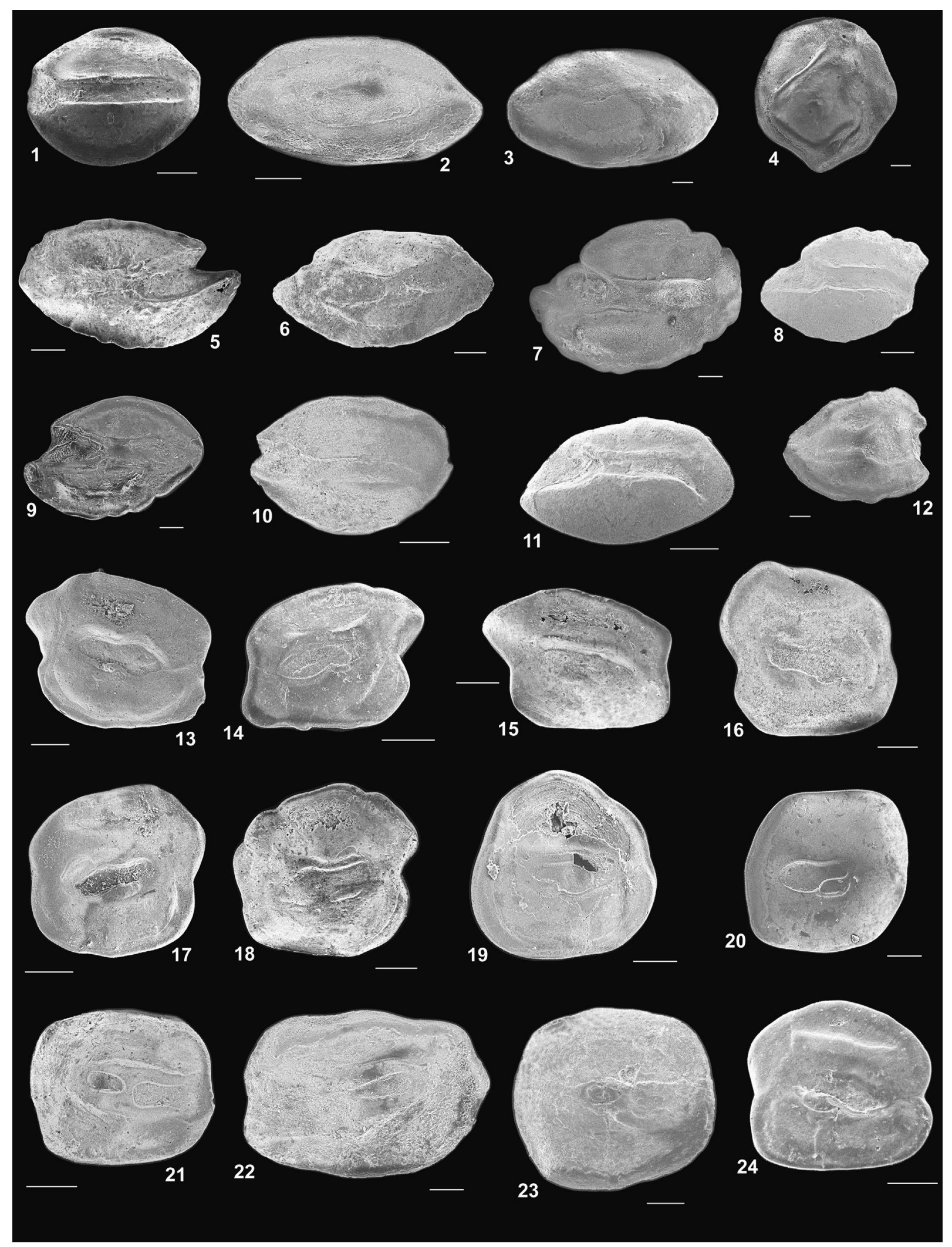

Fig. 8. SEM photographs of the studied otolith material. 1. Atherina boyeri Risso, 1810, Voutes 6. 2, 3. Grammonus ater (Risso, 1810), Voutes c. 4. Gadidae indet. Lapillus, Voutes 5. 5. Epigonus aff. denticulatus Dieuzeide, 1950, Voutes c. 6. Cepola macrophthalma (Linnaeus, 1758), Voutes 6. 7. Pagellus erythrinus (Linnaeus, 1758), Voutes 5. 8. Pagellus sp., Voutes 6. 9. Epigonus sp., Voutes 2. 10. Citharus linguatula (Linnaeus, 1758), Voutes 6. 11. Oblada melanura (Linnaeus, 1758), Voutes c. 12. Apogon sp., Voutes 6. 13. Gobius sp. 1 , Voutes 6. 14. Gobius cf. paganellus Linnaeus, 1758, Voutes a. 15. Gobius niger Linnaeus, 1758, Voutes a. 16. Lesueurigobius sanzi (de Buen, 1918), Voutes a. 17, 18. Lesueurigobius friesii (Malm, 1874), Voutes a. 19. Aphia minuta (Risso, 1810), Voutes 5. 20. “Gobidarum" sp. 1, Voutes 6. 21. Arnoglossus sp., Voutes 6. 22. Arnoglossu kokeni (Bassoli, 1906), Voutes a. 23. Bothidae indet., Voutes a. 24. Lesueurigobius suerii (Risso, 1810), Voutes a. Scale bars: $200 \mu \mathrm{m}(3,4,7,9,12,19,20,22,23) ; 500 \mu \mathrm{m}(1,2,5,6,8,10,13-18,21,24)$; $1 \mathrm{~mm}(11)$. 


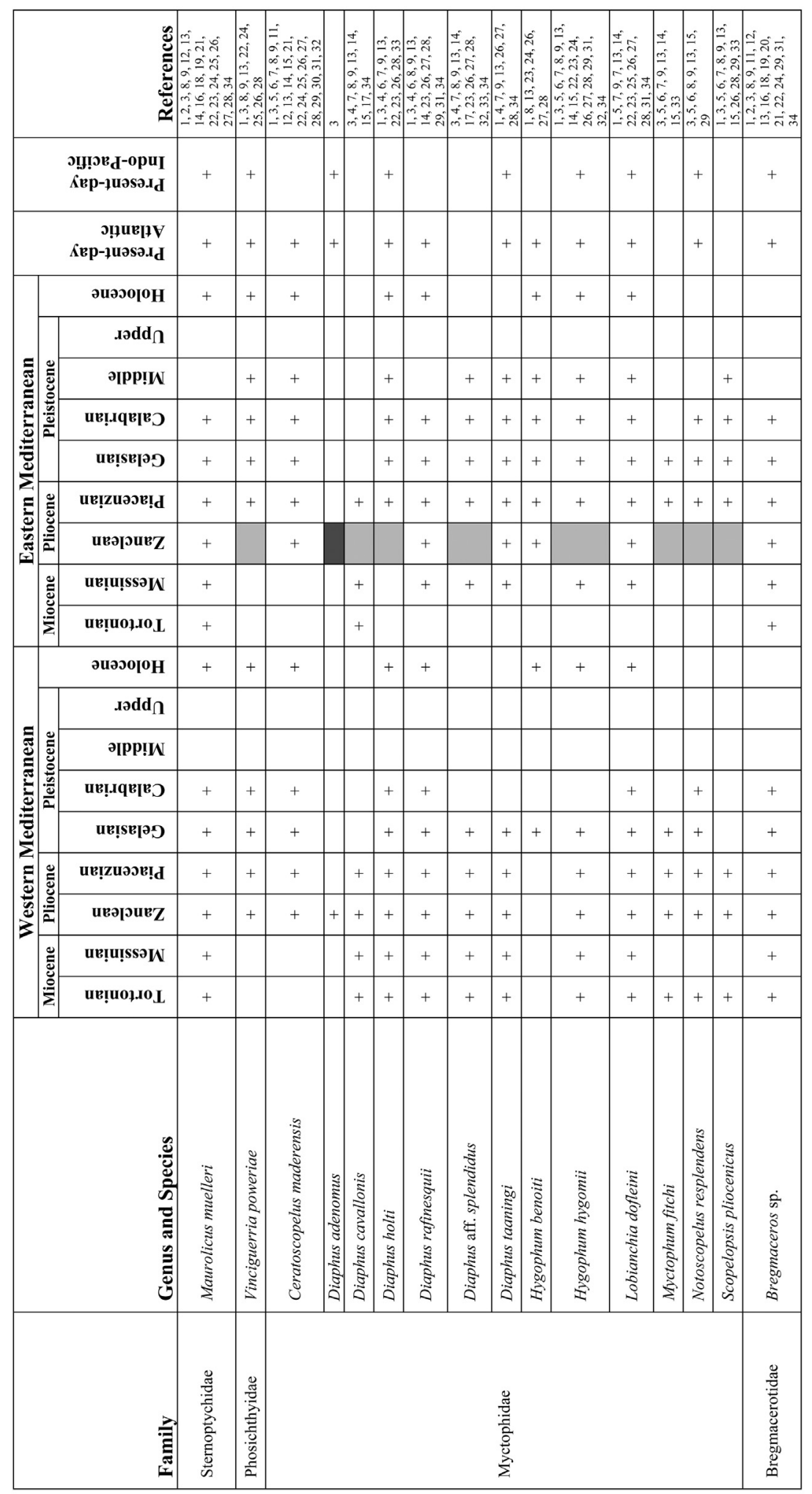

Fig. 9. Geographic and stratigraphic distribution of the identified pelagic fish taxa. Present-day distributions are according to the Fishbase database (Froese and Pauly, 2012). Dark grey cells indicate those taxa with first eastern Mediterranean Sea record in the corresponding time interval; light grey cells indicate taxa already reported in the Eastern Mediterranean for the corresponding time interval, but only in the Ionian realm. Present-day Indo-Pacific distribution of $M$. muelleri is confined to the eastern part of the Pacific Ocean. References: 1. Agiadi et al., 2011; 2. Landini and Sorbini, 1993; 3. Nolf and Girone, 2006; 4. Brzobohaty and Nolf, 2000; 5. Brzobohaty and Nolf, 1996; 6. Nolf and Martinell, 1980; 7. Nolf et al., 1998; 8. Girone, 2007; 9. Nolf and Cappetta, 1988; 10. Carnevale et al., 2006; 11. Markopoulou-Diakantoni and Kagiouzis, 2001; 12. Gaudant, 2002; 13. Landini and Sorbini, 2005; 14. Nolf and Cavallo, 1995; 15. Schwarzhans, 1979; 16. Anfossi et al., 1982; 17. Anfossi and Mosna, 1979; 18. Landini et al., 1990; 19. Gaudant 2001:20. Gaudant et al. 1994; 21. Sorbini, 1988; 22. Landini and Menesini, 1986; 23. Landini and Menesini, 1978; 24. Sorbini and Landini, 2003; 25. Landini and Varola, 1983; 26. Girone, 2000; 27. Girone and Varola, 2001; 28. Girone, 2003; 29. Anfossi and Mosna, 1972; 30. Aruta and Greco, 1980; 31. Bossio et al., 1986; 32. Nolf and Girone, 2000; 33. Anfossi and Mosna, 1976; 34. Girone et al., 2010; 35. Hoedemakers and Batllori, 2005. 
Sphenolithus spp. following the MNN14/15-MNN16 boundary (3.84 Ma, Lourens et al., 2004; Raffi et al., 2006) and just below the top of $D$. pentaradiatus paracme (3.61 Ma, Lourens et al., 2004), within the latest Zanclean.

\subsection{Stratigraphic and biogeographic affinities}

This study represents the first otolith-based reconstruction of a Zanclean fish paleofauna in the Eastern Mediterranean. The

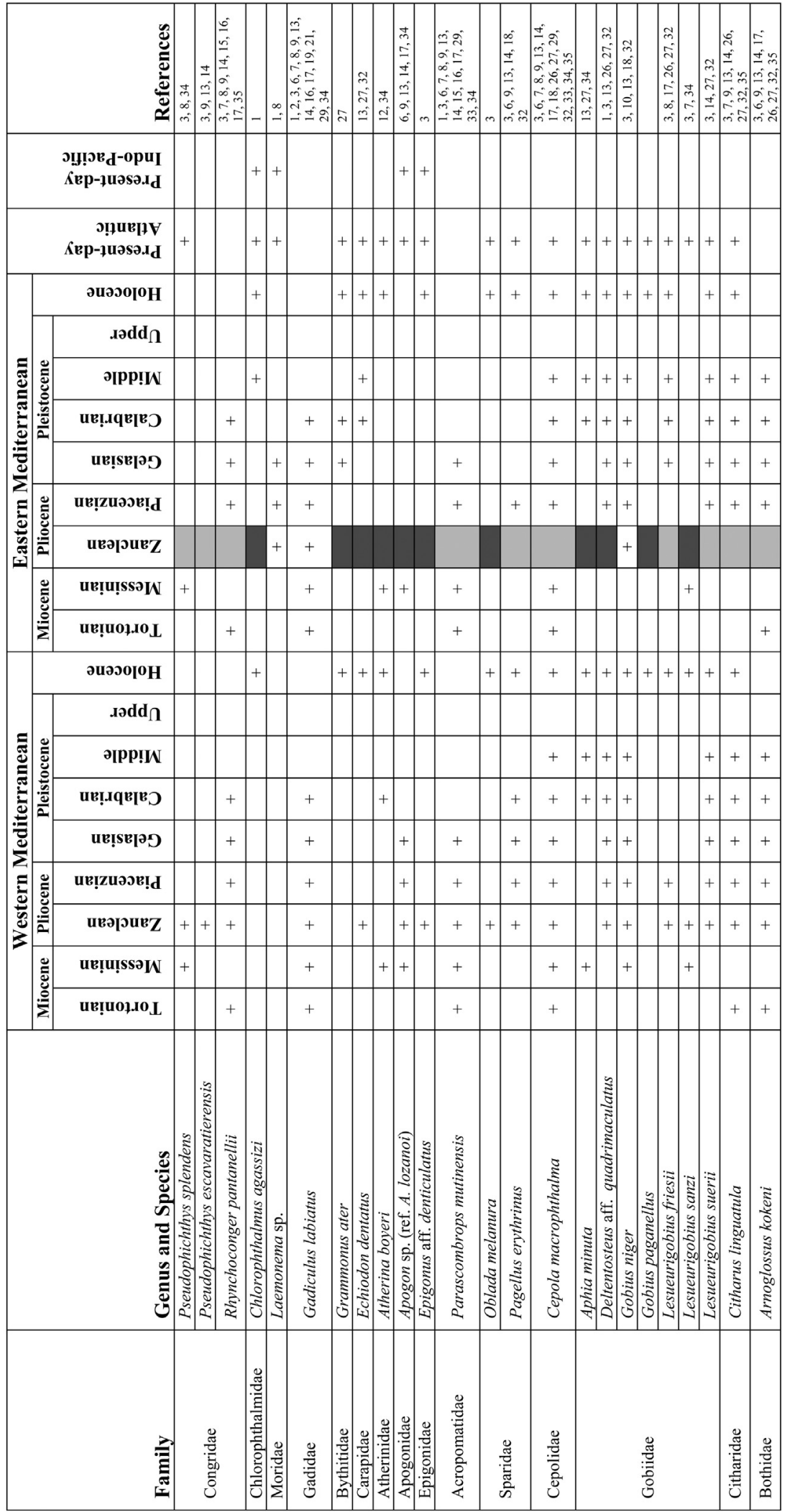

Fig. 10. Geographic and stratigraphic distribution of the identified benthic and benthopelagic fish taxa. At present, G. ater may be found in the Mediterranean, from the western sub-basin to the Adriatic Sea. Grey cells and reference numbers: see Fig. 9. 
stratigraphic and geographic distributions of the identified taxa are presented in Figs. 9 and 10. Overall, the stratigraphic distribution of 31 species is significantly extended. In particular, 12 species are reported for the first time in the Zanclean of the Eastern Mediterranean realm, while 19 species are reported for the first time in the Eastern Mediterranean outside the Ionian Sea. They illustrate a teleost fauna including both neritic and oceanic fishes.

The only previous reference to fossil fish otoliths in the Pliocene of the Eastern Mediterranean, outside the Ionian Sea, is the short note by Markopoulou-Diakantoni and Kagiouzis (2001). Unfortunately, the material examined in that paper is not available for reevaluation. Revisiting the Rethymnon section, outside the village Prassies, allowed the identification of the outcrop where the Late Miocene and Early Pliocene sediment samples were presumably taken by these authors. Systematic identification of the studied specimens could only be evaluated through the provided figures and photographs. As such, the specimens referred to Diaphus spp. can be positively identified at the generic level, Ceratoscopelus maderensis may be safely considered to be present, Bregmaceros albyi should best be referred to as Bregmaceros sp. due to the lack of data on the otolith morphological characteristics of the presentday species, and the specimens identified as Gobius vicinalis are better considered to belong to Lesueurigobius sp. based on their description and figures.

A significant observation made on Figs. 9 and 10 is that the Middle-Upper Pleistocene fish distribution is almost completely unknown. This is caused by lack of data due to the practical difficulty in finding appropriate specimens for this period.

Overall, the Pliocene Eastern Mediterranean ichthyofauna, as preserved in the Voutes area, presents a rich pelagic and a rather diverse benthopelagic and benthic component. The pelagic taxa include members of four families: Myctophidae, which is the most abundant and diverse, Sternoptychidae, Phosichthyidae, and Bregmacerotidae. The pelagic fish fauna does not present any striking differences neither from the western sub-basin fauna, nor from the Messinian fauna (Fig. 9).

Gobiids are by far the most diverse and abundant benthic fish family in the studied assemblages (Fig. 10). Six, out of the nine species identified, inhabit the Eastern Mediterranean coasts until today. Lesueurigobius sanzi may only be found today in the Atlantic Ocean and the western sub-basin, although it was present in both Mediterranean sub-basins prior to the Messinian salinity crisis. Gobiids generally appear to be quite resilient to the various environmental disturbances, persisting until today. The very limited data on the Eastern Mediterranean fish fauna is the most likely reason behind the striking gobiid absence from the Miocene assemblages. Judging from the state of the Western Mediterranean record however, it may be safely assumed that $D$. quadrimaculatus, G. paganellus, L. friesii and $L$. suerii are indeed Pliocene-introduced species.

In addition, the sparids Oblada melanura and Pagellus erythrinus first seem to enter the Mediterranean after the Messinian/Zanclean boundary. Furthermore, the presence of Chlorophthalmus agassizi in the Zanclean Eastern Mediterranean basin is notable since this very abundant extant species has only been recorded before, in the Middle Pleistocene sediments of the Ionian Sea (Agiadi et al., 2011). So far, Grammonus ater has only been found in the eastern subbasin from the Gelasian-Calabrian Ionian Sea (Girone and Varola, 2001). Finally, this is also the first post-Messinian Salinity Crisis Eastern Mediterranean record of the presently abundant species Atherina boyeri (Girone et al., 2006, 2010).

The Voutes fish fauna comprises both Messinian relics, as well as Pliocene introductions. When examining the stratigraphic distribution of the various fish taxa identified in this section, it is perceived that few are those Miocene species which seem to persist into the Pliocene, but do not last until today; these are D. cavallonis, M. fitchi, S. pliocenicus, G. labiatus, Apogon spp., P. mutinensis. Apart from Apogon spp., these are presently extinct taxa. In addition, it becomes more evident that some species were indeed first introduced to the Mediterranean after the salinity crisis, and maintained their place in the ecosystem until the present day; these are $V$. poweriae, $C$. maderensis, $H$. benoiti, C. agassizi, G. ater, E. dentatus, E. denticulatus, O. melanura, P. erythrinus, D. quadrimaculatus, G. paganellus, L. friesii, L. suerii, and $C$. linguatula. The present-day distributions of these latter species are either circum-global or Atlantic. The previously reported Indo-Pacific affinity of the Pliocene Mediterranean fauna (Gaudant, 2002) does not seem to apply in the case of the Voutes assemblages.

\section{Conclusion}

The added value provided through the examination of the Voutes fish fauna lies in the fact that this is the first systematic study of the evolution of the fish paleofauna in the Eastern Mediterranean. Indeed, Chlorophthalmus agassizi, an extant circum-global species very abundant in the Eastern Ionian Sea today, is documented for the first time outside the Ionian basin and in the Early Pliocene. This significantly affects any preconceptions regarding the Eastern Mediterranean deep-dwelling faunas, which may not be as much affected by climatic regimes, but rather more by other paleoceanographic factors such as circulation patterns, as already proposed by Agiadi et al. (2011). In addition, several systematic remarks are made on the otoliths of selected taxa. Finally, notable is the great diversity of the neritic benthic component, mostly comprised of gobiids, presumably reflecting locally different sea bottom conditions, but also of the mesopelagic myctophids. It can be safely assumed that the Voutes area offered several diverse habitats for different faunal components, but also that the environmental perturbations did not permit for a few species to competitively overwhelm others and dominate.

\section{Acknowledgements}

The authors thank Bruno Delrieu for the introduction to the studied section, as well as Dr. Gilles Escarguel, Dr. Giorgio Carnevale and Dr. Rostislav Brzobohaty for reviewing the manuscript. This research has been co-financed by the European Union (European Social Fund - ESF) and Greek national funds through the Operational Program "Education and Lifelong Learning" of the National Strategic Reference Framework (NSRF) - Research Funding Program "Heracleitus II. Investing in knowledge society through the European Social Fund".

\section{References}

Agiadi, K., Triantaphyllou, M., Girone, A., Karakitsios, V., Dermitzakis, M., 2010. Paleobathymetric interpretation of the fish otoliths from the lower-middle Quaternary deposits of Kephallonia and Zakynthos Islands (Ionian Sea, western Greece). Rivista Italiana di Paleontologia e Stratigrafia 116 (1), 63-78.

Agiadi, K., Triantaphyllou, M., Girone, A., Karakitsios, V., 2011. The early Quaternary palaeobiogeography of the eastern Ionian deep-sea Teleost fauna: a novel palaeocirculation approach. Palaeogeography Palaeoclimatology Palaeoecology 306, 228-242.

Anfossi, S., Brambilla, G., Mosna, S., 1982. La fauna del Pliocene di Taino (Varese). Atti dell' Instituto Geologico dell' Universita di Pavia 30, 83-102.

Anfossi, G., Mosna, S., 1972. Otoliti del Pliocene inferior di Lugagnano (Piacenza). Atti dell' Instituto Geologico dell' Universita di Pavia 23, 90-118.

Anfossi, G., Mosna, S., 1976. Otoliti del Pliocene inferiore della Liguria occidentale. Atti dell' Instituto geologico della Universita di Pavia 26, 15-29.

Anfossi, G., Mosna, S., 1979. La fauna ittiologica di Monteu Roero (Alba, Italia NW). Otoliti. Atti dell' Instituto Geologico della Universita di Pavia 27, 111-132.

Aruta, L., Greco, A., 1980. Otoliti dell' Emiliano di localita Olivella (PA) e del Pliocene superior di contrada Pipitone (AG) (Sicilia occidentale). Il Naturalista Siciliano ser $44(3-4)$, 101-117. 
Assis, C.A., 2005. The utricular otoliths, lapilli, of teleosts: their morphology and relevance for species identification and systematics studies. Scientia Marina 69 (2), 259-273.

Benda, L., Meulenkamp, J.E., Zachariasse, W.J., 1974. Biostratigraphic correlations in the eastern Mediterranean Neogene. Part I: Correlation between planktonic foraminiferal, uvigerinid, sporomorphal and mammal zonations of the Cretan and Italian Neogene. Newsletters on Stratigraphy 3, 205-217.

Bossio, A., Landini, W., Mazzei, R., Salcatorini, G., Varola, A., 1986. Studi sul Neogene e Quaternario della Penisola Salentina. I. La sequenza pliocenica di S. Andrea (Lecce) e il suo contenuto in pesci, ostracodi, foraminiferi e nannofossili. Atti della Societa Toscana di Scienze Naturali Memoire series A 92, 35-93.

Brzobohaty, R., Nolf, D., 1996. Otolithes de myctophides (poissons teleosteens) des terrains tertiaires d' Europe: revision des genres Benthosema, Hygophum, Lampadena, Notoscopelus et Symbolophorus. Bulletin de l'Institut Royal des Sciences Naturelles de Belgique, Sciences de la Terre 66, 151-176.

Brzobohaty, R., Nolf, D., 2000. Diaphus otoliths from the European Neogene (Myctophidae, Teleostei). Bulletin de l'Institut Royal des Sciences Naturelles de Belgique, Sciences de la Terre 70, 185-206.

Carnevale, G., Landini, W., Sarti, G., 2006. Mare versus Lago-mare: marine fishes and the Mediterranean environment at the end of the Messinian Salinity Crisis. Journal of the Geological Society London 163, 75-80.

Delrieu, B., Saint Martin, J.-P., Merle, D., 1991. Un modèle d' évolution tectonosédimentaire dans le domaine sud-égéen du Miocène supérieur : l'accident d'Aghia Varvara (Crète centrale, Grèce). Comptes Rendus de l'Academie des Sciences de Paris 313, 1043-1049.

Di Geronimo, I., Di Geronimo, R., Girone, A., La Perna, R., Rosso, A., 2003. Autochthonous and allochthonous assemblages from Lower Pleistocene sediments (Palione river, Sicily). Bolletino della Societa Paleontologica Italiana 42 $133-138$.

Fassoulas, C., 2001. The tectonic development of a Neogene basin at the leading edge of the active European margin: the Heraklion basin, Crete, Greece. Journal of Geodynamics 31, 49-70.

Froese, R., Pauly, D., 2012 (Eds.) Fishbase. World Wide Web electronic publication www.fishbase.org, version (10/2012).

Gaudant, J., 2001. Amnissos : un gisement clé pour la connaissance de l'ichthyofaune du Pliocène supérieur de Crète. Annalen des Naturhistorischen Museums in Wien 102A, 131-187.

Gaudant, J., 2002. La crise messinienne et ses effets sur l'ichthyofaune Néogène de la Méditerranée : le témoignage des squelettes en connexion de poissons téléostéens. Geodiversitas 24 (3), 691-710.

Gaudant, J., Delrieu, B., Dermitzakis, M., Symeonidis, N., 1994. Découverte d'une ichthyofaune marine dans les diatomites du Pliocène supérieur (Piacenzien) des environs d'Heraklion (Crète centrale, Grèce). Comptes rendus de l'Academie des Sciences, Paris, ser. 2 319, 589-596.

Girone, A., 2000. The use of fish otoliths for paleobathymetric evaluation of the Lower to Middle Pleistocene deposits in Southern Italy. Bollettino della Societa Paleontologica Italiana 39 (2), 235-242.

Girone, A., 2003. The Pleistocene bathyal Teleostean fauna of Archi (Southern Italy): palaeoecological and palaeobiogeographic implications, Rivista, Italiana. di Paleontologia e Stratigrafia 109 (1), 99-110.

Girone, A., 2007. Piacenzian otolith assemblages from northern Italy (Rio Merli section, Emilia Romagna). Bolletino della Societa Paleontologica Italiana 45 (2-3), 159-170.

Girone, A., Nolf, D., Cappetta, H., 2006. Pleistocene fish otoliths from the Mediterranean Basin: a synthesis. Geobios 39, 651-671.

Girone, A., Nolf, D., Cavallo, O., 2010. Fish otoliths from the pre-evaporitic (Early Messinian) sediments of northern Italy: their stratigraphic and palaeobiogeographic significance. Facies 56, 399-432.

Girone, A., Varola, A., 2001. Fish otoliths from the Middle Pleistocene deposits of Montalbano Jonico (Southern Italy). Bollettino della Societa Paleontologica Italiana 10 (3), 431-443.

Gradstein, F., Ogg, J., Smith, A., 2004. A Geological Time Scale. Cambridge University Press, $610 \mathrm{p}$.

Hoedemakers, K., Batllori, J., 2005. Fish otoliths from the Early and Middle Miocene of the Penedis (Catalunya, Spain). Batallerva 12, 105-134.

Landini, W., Menesini, E., 1978. L'ittiofauna Plio-Pleistocenica della sezione della Vrica (Crotone - Calabria). Nota preliminare. Atti della Società Toscana di Scienze Naturali Memorie SerieA 84, 1-14.

Landini, W., Menesini, E., 1986. L'ittiofauna pliocenica della Sez, di Stuni e suoi rapport con l'ittiofauna plio-pleistocenica della Vrica (Crotone, Calabria). Bolletino della Societa Paleontologica Italiana 25 (1), 41-63.
Landini, W., Menesini, E., Ragaini, L., 1990. Paleocomunita a molluschi e otoliti nel Pliocene di Castelfiorentino (Firenze, Italia). Atti della Societa Toscana diScienze Naturali Memoire, ser. A 97, 175-202.

Landini, W., Sorbini, L., 1993. Biogeographic and palaeoclimatic relationships of the Middle Pliocene ichthyofauna of the Samoggia Torrent (Bologna, Italy). Ciencias da Terra (UNL) 12, 83-89.

Landini, W., Sorbini, C., 2005. Evolutionary dynamics in the fish faunas of the Mediterranean basin during the Plio-Pleistocene. Quaternary International 140-141, 64-89.

Landini, W., Varola, A., 1983. L'ittiofauna del Pleistocene inferior di Matera. Thalassia Salentina 13, 16-45.

Lourens, L., Hilgen, F., Shackleton, N., Laskar, J., Wilson, D., 2004. The Neogene Period. In: Gradstein, F.M., Ogg, J.G. (Eds.), A Geologic Time Scale 2004. Cambridge University Press, pp. 409-440.

Markopoulou-Diakantoni, A., Kagiouzis, G., 2001. Otoliths from the lower Pliocene of the section Prassies (Rethymnon, NW-Crete), Systematics - Paleoecology. Bulletin of the Geological Society of Greece 34 (2), 577-584.

Meulenkamp, J.E., Dermitzakis, M., Georgiadou-Dikaioulia, E., Jonkers, H.A., Boerger, H., 1979. Field Guide to the Neogene of Crete. Publications of the Geology and Paleontology Department, University of Athens, Athens, $32 \mathrm{p}$.

Meulenkamp, J.E., Wortel, M.J.R., Van Wamel, W.A., Spakman, W., Hoogerduyn Strating, E., 1988. On the Hellenic subduction zone and the geodynamical evolution of Crete since the late Middle Miocene. Tectonophysics 146, 203-215.

Meulenkamp, J.E., Zwaan, G.J., van der Wamel, W.A., 1994. On late Miocene to recent vertical motions in the Cretan segment of the Hellenic Arc. Tectonophysics 234 $57-72$.

Nelson, J.S., 2006. Fishes of the World, 4th ed. John Wiley \& Sons Inc, New Jersey, $600 \mathrm{p}$.

Nolf, D., 1985. Otolithi Piscium. in: Schlutze H.P. (Ed.) Handbook of Paleoichthyology. vol. 10, p. 1-145, Stuttgart.

Nolf, D., Cappetta, H., 1988. Otolithes de poissons pliocènes du Sud-Est de la France. Bulletin de l'Institut Royal des Sciences Naturelles de Belgique, Sciences de la Terre 58, 209-271.

Nolf, D., Cavallo, O., 1995. Otolithes de poissons du Pliocène inférieur de Monticello d'Alba (Piemont, Italie). Rivista Piemontese di Storia Naturale 15, 11-40.

Nolf, D., Girone, A., 2000. Otolithes de Poissons du Pléistocène inférieur (Santernien) de Morrona (Sud Est de Pisa). Rivista Piemontese di Storia Naturale 21 $3-18$.

Nolf, D., Girone, A., 2006. Otolithes de poissons du Pliocène inférieur (Zancléen) des environes d'Alba (Piemont) et de la côte Ligure. Rivista Piemontese di Storia Naturale 27, 77-114.

Nolf, D., Mane, R., Lopez, A., 1998. Otolithes de poissons du Pliocène inférieur de Papiol, près de Barcelone. Palaeovertebrata $27(1-2), 1-17$

Nolf, D., Martinell, J., 1980. Otolithes de Téléostéens du Pliocène des environs de Figueras (Catalogne). Geologica et Palaeontologica 14, 209-234.

Raffi, I., Backman, J., Fornaciari, E., Palike, H., Rio, D., Lourens, L., Hilgen, F., 2006. A review of calcareous nannofossil astrobiochronology encompassing the past 25 million years. Quaternary Science Reviews 25 (23-24), 3113-3137.

Rio, D., Raffi, I., Villa, G., 1990. Pliocene-Pleistocene calcareous nannofossil distribution patterns in the western Mediterranean. In: Kastens, K.A., Mascle, J., et, al (Eds.), Proceedings of the ODP, Scientific Results, vol. 107. College Station TX ODP, pp. 513-533.

Schwarzhans, W., 1979. Otolithen aus dem Unter-Pliozan von Sud-Sizilien und aus der Toscana, Berliner geowissenschaft Abhand 8, 1-52.

Schwarzhans, W., 1986. Die Otolithen des Unter-Pliozan von Le Puget, S-Frankreich. Senckenbergiana Lethaea 67 (1-3), 219-273.

Sorbini, L., 1988. Biogeography and climatology of Pliocene and Messinian fossil fish of Eastern-Central Italy. Bolletino del Museo Civico di Storia Naturale di Verona $14,1-85$.

Sorbini, C., Landini, W., 2003. A new fish fauna in the Plio-Pleistocene of Monte Singa (Calabria, southern Italy). Bolletino della Societa Paleontologica Italiana 42 (1-2), 185-189.

Symeonidis, N., Konstadinidis, D., 1967. Observations on the Neogenic formations of Central Crete. Annales Géologiques des Pays Helléniques 19, 657-688.

Van Hinsbergen, D.J.J., Meulenkamp, J.E., 2006. Neogene supra-detachment basin development on Crete (Greece) during exhumation of the South Aegean core complex. Basin Research 18, 103-124.

Zachariasse, W.J., Hinsbergen, D.J.., Fortuin, A.R., 2011. Formation and fragmentation of a late Miocene supradetachment basin in central Crete: implications for exhumation mechanisms of high-pressure rocks in the Aegean forearc. Basin Research 23, 678-701 